SOCIAL SCIENCES. Education \& Educational Research

ORIGINAL RESEARCH

\title{
Verification of the System of Preparation of Future Specialists of the Social Sphere for the Prevention of Maladjustment of Pupils in Various Social Institutions
}

\author{
Author's Contribution: \\ A - Study design; \\ B - Data collection; \\ C - Statistical analysis; \\ D - Data interpretation; \\ E - Manuscript preparation; \\ F - Literature search; \\ G - Funds collection
}

Background and Aim of Study:

Material and Methods:

Results:

Conclusions:

Keywords:

Copyright:

DOI and UDC

Conflict of interests:

Peer review:

Source of support:

Information about the author:
Kostina V. V. ${ }^{1 \mathrm{ABCDEFG}}$

${ }^{1}$ H. S. Skovoroda Kharkiv National Pedagogical University, Ukraine

Received: 20.08.2018; Accepted: 15.09.2018; Published: 30.10 .2018

Abstract

The article is devoted to the problem of professional preparation of specialists in the social sphere.

The aim of the study: to describe the structure of conducting a pedagogical experiment on the research problem and determine its qualitative results.

During the implementation of the pilot study to determine the effectiveness of the the impact, made by developed system of training future specialists in the social sphere to prevent the maladjustment of pupils, on their professional competence, methods of comparing, analyzing and generalizing the results of the process of professional education in the control and experimental groups were used.

The logical structure of conducting an experimental research on the training of future social pedagogues and social workers for the prevention of maladjustment of pupils, which envisaged the implementation of five consecutive stages and methodological support for its implementation, as well as a system of criteria (motivational and valuebased, affective-conative, cognitive-instrumental and professional activity competencies) and corresponding indicators (interest and need of prevention of maladjustment of pupils; professional worldview as the basis for the development of professional culture, characteristics of temperament and will, that are ensuring the successful implementation of prevention of maladjustment of pupils; personal qualities necessary for working with vulnerable contingents, general-pedagogical potential, developed social intelligence, knowledge of the organization of socio-pedagogical and social activities of prevention of maladjustment of pupils in various social institutions; knowledge of the technological basis for the prevention of maladjustment of pupils; professional knowledge and skills in the prevention of maladjustment of pupils; experience in social-pedagogical and social preventive work).

Qualitative changes in personal and professional characteristics of future specialists of the social sphere are determined in accordance with the presented criteria system after the implementation of the forming part of the study.

training, specialists in the social sphere, prevention of maladjustment of pupils, social institutions, system of preparation of future specialists of the social sphere.

(C) 2018 Kostina V. V. Published by Archives of International Journal of Science Annals DOI 10.26697/ijsa.2018.1-2.02; UDC 378.147.013.42

The author declares that there is no conflict of interests

Double-blind review

\section{Departmental sources}

Kostina Valentyna Viktorivna (Corresponding Author) - https://orcid.org/0000-00032410-7497; Vkostina2014@gmail.com; Doctor of Philosophy in Pedagogy, Associate Professor, Doctorant of the Department of Pre-school, Primary School and Professional Education; H.S. Skovoroda Kharkiv National Pedagogical University; Kharkiv, Ukraine. 


\section{Introduction}

Analysis of scientific literature on the problem of determining the effectiveness of experimental research on the professional training of specialists in the social sphere (Bezpalko, 2015; Bogdanova, 2016; Vainola, 2009; Grinyova, 2014; Grishchenko, 2011; Gurenko, 2013; Zvereva, 2013; Kapska, 2010; Karpenko, 2007; Myshchik, 1997; Polischuk, 2011; Teslenko, 2007; Kharchenko, 2006, etc.) showed that the necessity of distinguishing the logical sequence of it and the selection of clear methodological support at all its stages was substantiated by the scientists.

On the basis of the generalization of the ideas of scientists (Goncharenko, 2010; Kiveryalg, 1980; Kraevskii, 2001; Yadov, 2007), it was determined that among the important conditions for the effective implementation of experimental research is its validity, representativeness, reproducibility, systemicity and optimality in choosing methods and tools. Taking into account the foregoing, in order to ensure the effectiveness of the pedagogical experiment, we have identified a certain logical structure of the experiment.

The aim of the study. To describe the structure of conducting a pedagogical experiment on the problem of professional training of future social pedagogues and social workers for prevention of maladjustment of pupils and determine its qualitative results.

\section{Material and methods}

In order to test the hypothesis of the study on the effectiveness of the developed system of professional training of future social pedagogues and social workers for the prevention of maladjustment of pupils from 2011 to 2018, a scientific and pedagogical experiment was conducted on the basis of the H. S. Skovoroda Kharkiv National Pedagogical University, A. S. Makarenko Sumy State Pedagogical University, Kryvyi Rih State Pedagogical University, and social institutions of the partner university of higher education network (Kharkiv secondary school No 36, Kharkiv gymnasium No 43, Kharkiv specialized secondary school No 134, CSSSDM of Kyiv and Kholodnogorsk districts, Kharkiv regional center of social \& psychological rehabilitation and Kharkiv regional children's center of social psychological rehabilitation "Harmony", social services of the charitable organization "Charitable Foundation "Caritas-Kharkiv" and charitable organization "Kharkiv Charitable Foundation "Blago", Kharkiv regional public organization "Health Culture").

Experimental work was based on the assumption that the modeling and implementation of the system of training future specialists in the social sphere to prevent maladjustment of pupils in various social institutions in a professionally-oriented educational space would ensure the professional readiness of future specialists in the social sphere (social pedagogues and social workers) to the corresponding kind of professional activity, where leading components would be competencies such as motivational and value-based, affective-conative, cognitive-instrumental, professional activity-based.
Research and experimental work were carried out in several stages, each of which provided for specific tasks to obtain data for further processing.

In the first stage (2010-2011), a search portion of the experiment was conducted. During this period the problem of prevention of pupils' maladjustment was studied as a phenomenon of social-pedagogical science and practice of social work, the peculiarities of their use in the system of professional training of future specialists of social sphere were studied and the initial theoretical principles of the research were specified.

During the pilot part of the experiment, the following activities were carried out:

1. Study of the attitude of teachers and students of the specialty "Social pedagogy" to the problem of preventing maladjustment of pupils.

2. Identification of the opportunities of the partner network of institutions in relation to the implementation of the professional training of specialists to the specified type of activity.

3. Diagnosis of the level of formation in specialists of the social sphere of preparedness for the implementation of prevention of maladjustment of pupils in various social institutions. Diagnostic tools of this part of the experiment consisted of methods of observation, interviews, questionnaires, oral questioning, document analysis.

In the second stage (2012-2013) a theoretical analysis of literary sources on the problem of training future specialists in the social sphere for the prevention of maladjustment of pupils was conducted, there was systematized and generalized the scientific and pedagogical experience of implementing the professional education of future social pedagogues and social workers to the appropriate kind of professional activity, scientific assumptions were formed, further study of the research problem continued. At this time, the task of the study, its concept, working hypothesis were formulated, the toolkit for the experiment was developed. For this part of the study, theoretical methods of research (analysis, synthesis, comparison, abstraction, generalization, modeling) were widely used.

At the third stage of the research (2013-2014), the qualitative part of the experimental study was conducted, during which the initial level of formation of professional competence of future social pedagogues and social workers for the prevention of maladjustment of pupils was determined. The diagnosis of the level of formation in future specialists of the social sphere of preparedness for the implementation of the prevention of maladjustment of pupils in various social institutions at the beginning of the experiment, was conducted using such tools as observation methods, interviews, questionnaires, oral questioning, testing, document analysis, and mathematical statistics. To perform diagnosis of the formation of the readiness of future specialists of the social sphere to prevent the maladjustment of pupils, were used the following criteria and markers: motivational and value-based (interest and need to work on prevention of 
maladjustment of pupils, professional outlook), affective-conative (features of temperament and will, personal qualities needed to work with vulnerable contingents), cognitive-instrumental (general pedagogical potential, social intelligence; knowledge of the organization of socio-pedagogical and social activities for the prevention of maladjustment of pupils in various social institutions; knowledge of the technological basis for the prevention of maladjustment of pupils) and professional activity-based (professional knowledge and skills for the prevention of maladjustment of pupils; experience of socialpedagogical and social preventive work). On this basis, four levels of formation of the readiness of future social pedagogues and social workers to prevent maladjustment of pupils were identified (Kostina, 2017, pp. 13-16): insufficient, primary, professionallyqualified, professionally-specialized. The determination of these levels is given in Table 1 and the control and experimental groups are selected.

In the fourth stage (2013-2017), the forming and control parts of the experiment were conducted. During this period, a system of professional training for the prevention of maladjustment of pupils was introduced into the process of professional education of future social pedagogues and social workers. The formative stage of the experiment was carried out on the basis of the H.S. Skovoroda Kharkiv National Pedagogical University.

Students of specialties "Social pedagogy" and "Social work" took part in it. Among the methods of research at this stage, the pedagogical experiment, for which the scientific and methodical tools developed during the course of work were used, as well as the diagnostic methods by which the diagnostics and analysis of the formation of readiness of future social pedagogues and social workers were carried out, was determined to be the the main one.

Among the theoretical methods used at this stage of the study were analysis, grouping, synthesis, comparison, induction, deduction. The statistical analysis of the results of the study was based on the non-parametric Pirson's criterion $\chi^{2}$.

The probability and validity of experimental data was provided through the use of standardized techniques and the organization of the experiment in the real educational process of educational institutions and social assistance institutions of the partner network of higher educational establishments.

During the fifth stage (2017-2018), the processing and analysis of the results of the pedagogical experiment with the wording on this basis of relevant conclusions was carried out, the dissertation work was completed and the prospects for further research of the problem of training of future specialists of the social sphere for prevention of maladjustment of pupils were determined. Among the main methods used at this stage were comparison, analysis, grouping, synthesis, deduction, induction.

\section{Results}

During the pilot part of the study, we conducted an oral and written survey of social specialists working in educational and social assistance institutions with students who are prone to maladjustment. The data obtained allowed us to determine that most specialists (70.2\%) noted that during work with vulnerable contingents (maladjusted pupils, their parents or those who replace them) have many difficulties, and teachers and educators of such children need help, they often $(65.0 \%)$ are not fully prepared for the organization of the social-educational environment for such children, and most specialists have a desire to take the necessary training course $(70.2 \%)$, which confirmed the need to improve the efficiency of the process of training future social pedagogues and social workers in implementing prevention of maladjustment of pupils.

When asked a question "Please assess your own readiness to create a social and educational environment for maladjusted pupils in the social institution where you work", the majority of respondents $(52.6 \%)$ answered that they were half ready for the corresponding professional job, while others (47.4\%) showed even less readiness for this type of activity. And the question "about the importance of implementing comprehensive preventive activities" $37.0 \%$ of respondents answered affirmatively. To the question "Would you like to pass the special course "Prevention of maladjustment of pupils in various social institutions", $61.4 \%$ answered - yes, will do so with pleasure; $26.3 \%$ - yes, if my superiors will give me an opportunity, which confirms the need for professional training of specialists to the appropriate type of activity.

In order to conduct a pedagogical experiment on checking the hypothesis in relation to determining the effectiveness of the developed system of professional training of future specialists in the social sphere for the prevention of maladjustment of pupils, we conducted a qualitative part of the study, during which we ran diagnostics against a contingent of students - future specialists of the social sphere, of the H. S. Skovoroda Kharkiv National Pedagogical University, Kryvyi Rih State Pedagogical University, A. S. Makarenko Sumy State Pedagogical University, and we also selected the contingent of participants in the experiment (control and experimental groups), which at the beginning of the formative stage of the experimental study almost did not differ according to the criteria and indices of the research, as defined in Table 1.

According to Karpenko (2007, p. 206), based on the content of the State Standard in the field of social work, "the process of professional development includes five stages: 1) introduction (the formation of personal intentions, the conscious choice of the profession, taking into account psychological peculiarities); 2) professional training (formation of professional orientation of the system of knowledge, skills and abilities, mastering the experience of solving professional problems and situations); 3) professional adaptation (conscious admission to the profession, mastering the new social role, professional selfdetermination, mastering the experience of independent performance of professional activities in different directions and needs of the social sphere); 
Table 1. Criteria, indicators and levels of readiness of future social pedagogues and social workers to prevent maladjustment of pupils.

\begin{tabular}{cccc}
\hline $\begin{array}{c}\text { Readiness } \\
\text { components }\end{array}$ & $\begin{array}{c}\text { Readiness } \\
\text { criteria }\end{array}$ & $\begin{array}{c}\text { Readiness } \\
\text { indicators }\end{array}$ & Readiness levels \\
\hline
\end{tabular}

1) insufficient (the future specialist does not have motivation and interest in the prevention of maladjustment of pupils, has poorly developed professional outlook (undeveloped professional ideals, values, lack of professional beliefs);

- Interest and need for prevention of maladjustment of Motivations pupils; and values - Professional outlook as the basis for development of

Personal potential

Affective-

- The peculiarities of temperament and will, which ensure the successful implementation of

conative the prevention of pupils; - Personal qualities needed to work with vulnerable contingents

- General pedagogical potential; intelligence; organization of socio-pedagogical Cognitive- and social activities instrumental maladjustment of pupils in various social institutions; - Knowledge of the technological basis of implementation of prevention of maladjustment of professional culture. - Developed social - Knowledge of the Cognitive-
instrumental for the prevention of

2) primary (the future specialist has poorly developed motivation and there is only an occasional interest in preventing maladjustment of pupils, poorly developed professional outlook (unclear professional ideals, values, unconscious professional beliefs); 3) professionally-qualificational (the future specialist has sufficiently developed motivation and interest in the prevention of maladjustment of pupils, developed professional outlook (realized professional ideals and values);

4) professional-specialized (the future specialist is highly motivated and interested in the implementation of activities and research on the prevention of maladjustment of pupils, a fully developed professional worldview (available professional ideals, values and professional beliefs).

1) insufficient (future specialist has no volitional qualities that result in the manifestation of adequate professionally-required behavior in conditions of interaction with vulnerable contingents, also has low indicators of stress resistance, empathy and other personality traits);

2) primary (future specialist has weakly developed volitional qualities that determine the manifestation of adequate professional behavior in the context of interaction with vulnerable contingents, not fully developed stress resistance, empathy, ability to reflect and facilitation);

3) professionally-qualificational (the future specialist has sufficiently developed volitional qualities that determine the manifestation of adequate professional behavior in the context of interaction with vulnerable contingents; fully developed humanity, benevolence, tolerance, stress resistance, empathy and ability to reflect, facilitation);

4) professional-specialized (the future specialist has high indicators of the development of volitional qualities that determine the manifestation of adequate professional behavior in the context of interaction with vulnerable contingents, fully developed humanity, benevolence, tolerance, creativity, stress resistance, empathy, ability to reflect and facilitation, the student demonstrates the ability to manage own behavior and positively influence the behavior of others).

1) insufficient (future specialist has no general pedagogical potential and knowledge on prevention of maladjustment of pupils and implementation of technologies and methods of work in that direction, underdeveloped social intelligence (missing prosocial orientation of the individual, very low self-efficacy, absent emphatic interest and attitude of seeing value in others);

2) primary (future specialist has poorly developed general pedagogical potential and knowledge system for the prevention of maladjustment of pupils and technological bases of work in the indicated direction, they are fragmented, there is poorly developed social intelligence (almost missing expressed pro-social orientation of the individual, low self-efficacy, almost absent empathic interest and attitude of seeing value in others);

3) professionally-qualificational (the future specialist has fully developed general pedagogical potential and knowledge on the prevention of maladjustment of pupils in various social institutions and the application of technologies and methods of work in this direction in various social institutions, sufficiently developed social intelligence (expressed pro-social orientation of personality, high self-efficacy, possesses empathic interest and attitude of seeing value in others);

4) professional-specialized (the future specialist has fully developed generalpedagogical potential and system of knowledge on the prevention of maladjustment of pupils and application of technologies and methods of work in this direction in various social institutions, he or she demonstrates knowledge of system-forming links between them and interest to conduct analysis of research prevention of maladjustment of pupils).

1) insufficient (the future specialist has poorly developed individual professional skills in the prevention of maladjustment of pupils in different social institutions; there is no experience of volunteer initiatives and practices for the prevention of maladjustment of pupils in different social institutions);

- Professional skills and skills in the prevention of maladjustment of pupils (gnostic; predictive;

Professional designing; activity-based organizing communicative; evaluating);

- Experience in social-pedagogical and social prevention work. 2) primary (the future specialist has a poorly developed system of professional skills for the prevention of maladjustment of pupils in various social institutions; there is a fragmentary experience of preventing maladjustment of pupils in different social institutions during educational practices);

3) professionally-qualificational (the future specialist has a fully developed system of professional skills for the prevention of maladjustment of pupils in various social institutions; possesses volunteer experience and experience in preventing maladjustment of pupils in different social institutions during educational and handson practices);

4) professional-specialized (the future specialist has fully developed system of professional skills for preventing maladjustment of pupils in different social institutions, there exists volunteering experience, successful completion of practical work, as well as professional experience in preventing maladjustment of pupils in different social institutions while working in a position of social pedagogue or social worker). 
4) professionalization (formation of a professional position, integration of personal and professional qualities and skills in stable professionally meaningful education, qualified performance of professional activity); 5) professional mastery (full, multifaceted realization of personality in professional activity on the basis of integrated psychological and pedagogical formations)".

Taking into account the above, with the aim of creating a system of professional training of future specialists in the social sphere to prevent maladjustment of pupils, during the organization of the formative stage of the study, we have identified such important components, scientific and methodological support, in accordance with the model of developed by us system of professional training (Kostina, 2018, pp. 176-177), the introduction of which in the educational process of higher educational institutions contributed to the creation of a professionally oriented educational space, which ensures increased efficiency of professional readiness of specialists for conducting the appropriate type of professional activity: 1) to create the conditions for effective introduction of future professionals in prevention of maladjustment of pupils, in different social institutions has been introduced the work of the volunteer group within the Student Scientific Society (SSS); 2) in order to increase the effectiveness of the students' professional training, a workshop is organized at various social institutions as well as during the training of future social pedagogues and social workers, with the introduction of elements of personality-oriented developmental techniques within the main disciplines of professional training and corresponding special courses; 3 ) in order to improve the quality of professional adaptation of future social pedagogues and social workers in the process of research activities, an educational and developmental environment for the work of SSS in the conditions of higher educational establishments and at the bases of the affiliate network has been created; 4) for the successful professionalization of future specialists in the social sphere, conditions have been created for the gradual growth of social and personal activity of students in social and project volunteering activities; 5) enrichment of the elements of reflective and creative environments during study with the use of ethnopedagogical means and animation activities (use of folklore, means of theatricalization, artistic creativity, etc.), which provide activation of the creative potential of future specialists and encourage them to find their own professional style and increase pedagogical skill. According to the above-mentioned stages of formation of the professional readiness of future specialists of the social sphere for the prevention of maladjustment of pupils, we determined certain tasks, forms and methods that were used at each of those stages during the pilot study (see Table 2).

The process of professional introduction among students of experimental groups was conducted by involving them in a supportive educational and professional space with the participation of senior students who are active members of the SSS and the participants of the volunteer group work.

At the end of each September, the social-educational event "Welcome to Freshmen" is organized, during which they had an opportunity in warm atmosphere to get acquainted with the best achievements of students and teachers of specialties "Social pedagogy" and "Social work" of senior years of study, with opportunities of professional and personal growth in teaching and extracurricular activities, traditions and important events in the life of the Department of Social Pedagogy and the Faculty of Psychology and Sociology of Skovoroda Kharkiv National Pedagogical University, and also feel like part of a large family of future social pedagogues, social workers.

During this meeting, close mentor-like relations are established between the first-year students and the Master's Degree students of the fifth year of study active participants of the SSS, who from that moment on begin a conscientious and responsible work to involve them in the work of the SSS first as volunteers, and then, gradually including them in active scientific activity. Starting from this day, the SSS activists conduct meticulous work in extracurricular time with all first-year students, and, based on their own experience in writing scientific research papers and the provisions on holding a competition "Freshmen's Scientific Debut", gradually choose the capable ones and prepare them for participation in the corresponding general university competition, creating conditions for effective professional choice, as well as developing their own personal and professional potential in the indicated direction.

The organization and holding of the "Freshmen's Scientific Debut" competition is the next stage in creating the conditions for ensuring a positive professional choice of future specialists in the social sphere, as well as one of the stages of obtaining professional skills for students of the fifth and sixth years of study, as they have to organize and hold it. All first-year students take part in the competition, but depending on their own abilities and desires, could perform in different roles: the speaker announcing the results of scientific research at the competition (students who are most capable of scientific activity); speaker support group (students developing their own professional opportunities for teamwork and facilitation support); students-observers (students who are not yet active in scientific professional activities, but are trained on the example of others).

Furthermore, during the study year, first-year students are actively involved with the SSS leaders who are part of the volunteer group, to carry out various social and educational preventive measures in various social institutions of the partner network as volunteers (general educational institutions, etc.). In carrying out volunteer initiatives, future specialists in the social sphere have the opportunity to see in practice what the essence of social and educational interaction is, which important characteristics determine the success of its implementation, which helps them to more consciously enter the environment of professional interaction, finding their own reserves and opportunities. 
Table 2. Stages and methods of experimental research on the formation of the professional readiness of future social pedagogues and social workers to prevent maladjustment of pupils.

\begin{tabular}{|c|c|c|}
\hline Stages & Tasks & Forms, methods \\
\hline Introduction & $\begin{array}{l}\text { Formation of personal intentions in relation to } \\
\text { future professionalisation in the direction of } \\
\text { prevention of maladjustment of pupils, conscious } \\
\text { choice of the appropriate professional orientation } \\
\text { taking into account their own psychological } \\
\text { peculiarities }\end{array}$ & $\begin{array}{l}\text { The work of the volunteer group within the SSS, involving } \\
\text { future specialists in social and educational activities, the } \\
\text { educational work of the faculty and specialty (scientific and } \\
\text { creative contests "Freshmen's Scientific Debut", educational } \\
\text { events "Welcome to Freshmen", "The initiation of freshmen into } \\
\text { social workers") }\end{array}$ \\
\hline Professional training & $\begin{array}{l}\text { Formation of a professionally-oriented system of } \\
\text { knowledge, skills and abilities in relation to the } \\
\text { essence and features of the prevention of } \\
\text { maladjustment of pupils in various social } \\
\text { institutions, mastering the experience of solving } \\
\text { professional problems and situations in the } \\
\text { specified direction of professional activity }\end{array}$ & $\begin{array}{l}\text { Introduction of elements of personality-oriented developmental } \\
\text { techniques within the main disciplines of professional training } \\
\text { and corresponding special courses, as well as during the practice } \\
\text { in various social services }\end{array}$ \\
\hline $\begin{array}{l}\text { Professional } \\
\text { adaptation }\end{array}$ & $\begin{array}{l}\text { A conscious assimilation of the professional duties } \\
\text { of a social pedagogue and a social worker of a } \\
\text { certain social institution during practice in the } \\
\text { context of preventive work with pupils, mastering a } \\
\text { new social role, professional self-determination in } \\
\text { the direction of prevention of maladjustment of } \\
\text { pupils, mastering the experience of self-fulfilling } \\
\text { professional activities to prevent maladjustment of } \\
\text { pupils in different institutions of the social sphere }\end{array}$ & $\begin{array}{l}\text { Training course "Practical readiness of future specialists of the } \\
\text { social sphere for preventive work with vulnerable contingents" } \\
\text { during the practice in the educational institutions and social } \\
\text { services; } \\
\text { Creation of an educational and developing environment for the } \\
\text { future specialists of the social sphere in the conditions of higher } \\
\text { educational establishments and at the bases of the partner } \\
\text { network; provision of opportunities for carrying out of scientific } \\
\text { social-pedagogical research on bases of the partnership with the } \\
\text { higher educational establishments of the network }\end{array}$ \\
\hline Professiona-lization & $\begin{array}{l}\text { Formation of a professional position in relation to } \\
\text { the coordination role of a specialist in the social } \\
\text { sphere in the prevention of maladjustment of pupils, } \\
\text { the integration of personal and professional } \\
\text { qualities and skills in stable professional education, } \\
\text { providing skilled performance of professional } \\
\text { activities in the comprehensive prevention of } \\
\text { maladjustment of pupils }\end{array}$ & $\begin{array}{l}\text { Ensuring permanent work of the volunteer group of future social } \\
\text { pedagogues and social workers, which plans and implements } \\
\text { social and educational preventive measures in various social } \\
\text { institutions of the partner network and creates conditions for the } \\
\text { gradual growth of social and personal activity of students in } \\
\text { social and preventive volunteering activities }\end{array}$ \\
\hline Mastery of profession & $\begin{array}{l}\text { Full, multifaceted realization of the potential of the } \\
\text { personality of the future specialist of the social } \\
\text { sphere in the professional activity on the prevention } \\
\text { of maladjustment of pupils on the basis of the } \\
\text { formation of his personal (motivational \& value- } \\
\text { based, affective-conative) and professional } \\
\text { (cognitive-instrumental and professional activity) } \\
\text { competency to the specified type of activity }\end{array}$ & $\begin{array}{l}\text { Ensuring the operation of SSS: } \\
\text { organization and conducting of social and educational work at } \\
\text { the bases of practice (secondary school No } 36 \text {, secondary school } \\
\text { No } 134 \text {, secondary school No } 156 \text {, Gymnasium No } 43 \text {, } \\
\text { Gymnasium No } 169 \text {, social services of the partner network); } \\
\text { organization and conducting of partnership interaction with } \\
\text { students and scientific and pedagogical workers of social sphere } \\
\text { within the framework of annual joint scientific seminar in } \\
\text { Kharkiv Humanitarian and Pedagogical Academy; } \\
\text { Organization and conducting of the annual inter-university } \\
\text { student's scientific conference "Actual problems of research in } \\
\text { the field of social pedagogy and social work" in } \\
\text { H. S. Skovoroda Kharkiv National Pedagogical University }\end{array}$ \\
\hline
\end{tabular}

The final stage of the organization of the process of professional inclusion of future specialists in the social sphere is "Initiation of Freshmen into Social Workers", carried out by Master's Degree students in the spring, during the annual student's scientific and practical conference "Actual problems of research in the field of social pedagogy and social work".

The next stage of professional development of future specialists in the social sphere is the professional training that was carried out in experimental groups and provided for examination of the effectiveness of the developed methodological support, the main elements of which were: general-professional preparation for the prevention of maladjustment of pupils (supplementing the professional disciplines of the training of future social pedagogues and social workers ); special training of future specialists in the social sphere to work on the prevention of maladjustment in various social institutions (introduction of special courses "Guardianship and Care", "Designing the social and educational environment for children and youth organizations", "Ethnopedagogy", "Social work for the formation of a healthy lifestyle").

An important component of the training of future professionals in the social sphere for prevention of maladjustment of pupils is organization of a training workshop for first- and second-year students, during which they visit social institutions of the partner network (center of social services for families, children and youth (CSSFCY), centers for social and psychological rehabilitation for children, special education centers, family-type orphanages, probation services, etc.) in order to get acquainted with the specifics of the social work of the institutions involved in the prevention of maladjustment of children and young people.

In order to create conditions for the professional adaptation of future specialists to performing professional tasks in a certain social institution, the organization of training and hands-on practices at CSSFCY and secondary schools during third and fourth years of university study is organized, during which students have an opportunity to get acquainted with the essence and specifics of the work of a social worker and a social pedagogue, who coordinates the 
activities of certain social institution for the prevention of maladjustment of pupils.

In order to become more aware of the entry into the professional world of specialists in the social sphere, students undergo a training course "Practical readiness of future specialists of the social sphere for preventive work with vulnerable contingents" within the framework of hands-on practice in the educational institutions and social services, during which, with the help of qualified methodologists that are working in the social sphere, they have the opportunity to find out their level of personal readiness for the implementation of preventive activities, get acquainted with the problems and difficulties of socialization which arise in children and young people and learn effective forms, methods, means and methods of professional preventive activities with pupils.

During the practice, students learn the experience of methodologists of the partner network of institutions, on the basis of generalization of which they have to independently prepare and implement several social and educational preventive measures with the involvement of specialists of social services and resources of the institution where they are trained. Also, at the bases of practice of the affiliate network of institutions, students - future social pedagogues and social workers, have the opportunity to organize and conduct activities within their own research, not limited to their own practice, which also contributes to a more effective social adaptation to a particular type of professional activity.

To ensure the effective passing of professional adaptation trials, it is necessary to create conditions for the continuous professional activity of future specialists to increase their social activity and creativity. To this end, senior students who are active members of the SSS are involved in the organization and conduct of various volunteer initiatives within the university and various social institutions of the city, as coordinators. This work enables future social pedagogues and social workers to determine their own reserves and resources, which contributes to a more informed assimilation of the learning information during senior years of study and prevents the development of professional burnout by future professionals who are constantly enriching their personal and professional resources, widening the circle of their own professional interaction.

In order to create conditions for the development of professional skills of future social pedagogues and social workers in the conditions of the work of the SSS, the organization and thematic meetings of the scientific student society was introduced, during which senior students that are active members of the SSS, who are winners of the All-Ukrainian Olympiads, tournaments and contests in specialties "Social pedagogy" and "Social work" have the opportunity to prepare and hold a meeting of a scientific circle on a certain topic that is the subject of their own science research and familiarize junior students with its theoretical and practical aspects and share their practical skills in social work within a particular issue, while implementing their own master class. During the meetings of the scientific circle for the purpose of exchange of experience, leading experts of social services of the partner network of higher educational establishments, which introduce innovative methods and technologies of work with maladjusted children and young people, may be involved. Thus, during the organization of the formative stage of the experiment, the specialists of the Charitable Foundation "Kharkiv Charitable Foundation "Blago" and the Charity Fund of Charitable Organization "Caritas-Ukraine" in order to create opportunities for increasing the professional competence of future specialists of the social sphere to prevent the maladjustment of pupils, provided conditions for their preventive social and pedagogical activities with the "risk" group of adolescents and children who moved from the Anti-Terrorist Operation (ATO) area to the city of Kharkiv, subjects of probation, children from needy families and families with a lot of children, on a voluntary basis. Also, future social pedagogues and social workers within the framework of social interaction with the educational schools of the partner network (School No 36, Gymnasium No 43, School No 134, School No 156, Gymnasium No 169 of the city of Kharkiv) organized and conducted a number of events: with class leaders and the pedagogical team ("Using origami techniques in social and pedagogical activities for the prevention of aggressive behavior of pupils", "Using ethnopedagogical means in preventing deviant behavior of pupils", "Prevention of bullying in children and youth environment", etc.); with pupils ("What do I know about trafficking in human beings?", "I choose to be healthy", "Parallel virtual world: the possibility of self-assertion or the illusion of opportunities", "We are different, but we are equal!", etc.), and also developed informational booklets for parents in order to improve their pedagogical culture on the problem of prevention of maladjustment of pupils ("Prevention of alcohol addiction in adolescents", "Prevention of bullying in the study environment", "Prevention of aggressive behavior of younger pupils through means of fairy tales", "Prevention of sexual deviations in pupil behavior", "Prevention of deviant behavior of younger schoolchildren from "at risk" families, by using literary means", etc.).

An important direction in shaping the professional skills of future specialists in the social sphere is the organization of joint seminars, tournaments and conferences with specialists of other higher educational institutions. For this purpose, we have since 2008 on the basis of H.S. Skovoroda Kharkiv National Pedagogical University organized an annual interuniversity students' scientific and practical conference "Actual problems of research in the field of social pedagogy and social work", as well as in conjunction with the Department of Social Pedagogy of the Kharkiv Humanitarian and Pedagogical Academy, on their base, starting in 2013, the launch of scientific and practical workshop for social professionals, in which future social pedagogues and social workers from different universities have the opportunity to get acquainted with the results of research of leading scientists in social sphere and present results of their 
research and publish a thesis. During the abovementioned events, students also have the opportunity to expand their own professional contacts with leading scholars and specialists in the social sphere, which, as experts, take on workshops and conferences.

\section{Discussions}

The analysis of the research results on the problem of the professional training of future specialists in the social sphere allowed us to confirm the need to create the necessary conditions for the creation, in the process of their professional training and professional competence development, of the motivational (Bogdanova, 2016; Grishchenko, 2011; Melnyk, 2017), cognitive (Gurenko, 2013; Karpenko, 2007), practical (Vainola, 2009; Polishchuk, 2011) and personal (Olefir, 2016; Kaidalova, 2008; Melnyk and Pypenko, 2017) aspects of professional readiness for a certain kind of professional activity. Taking into account the aforesaid, we have organized a pedagogical experiment to verify the effectiveness of the impact on the formation of the professional competence of future social pedagogues and social workers to prevent the maladjustment of pupils, of the developed system of their professional training to the specified type of activity in the conditions of the created professionally directed environment on the basis of institution of higher education and bases of practice of the partner network of social institutions that carry out relevant activities with a designated contingent.

The representativeness, validity and reliability of the results obtained during the experimental study are provided by using a set of methods that are tailored to suit its purpose, tasks and reproduction possibilities.

\section{Conclusions}

According to the results of the introduction of the formative stage of the experimental study, it can be argued that the students of the experimental group with the introduction of the developed system of professional training, which provided for the gradual implementation of the five stages (introduction, professional training, professional adaptation, professionalization and professional mastery), there is a steady dynamics growth of indicators with all major research criteria. Among the qualitative changes one can distinguish the following characteristics: growth of social activity, confidence in own professional ability and independence in the performance of professional tasks; manifestation of the facilitation position in interaction with pupils who are prone to maladjustment; development of professional mobility and readiness to solve problems of prevention of maladjustment of children and youth in various social institutions, which testifies to the growth of their professional competence in preventing maladjustment of pupils.

Further research needs to be done to determine the dynamics of quantitative changes in the level of professional training of future specialists in the social sphere based on the above-mentioned criteria and indicators based on the results of the control phase of the pilot study.

\section{References}

Bezpalko, O. (2015). Kompetentnisnyi spektr maibutnoho sotsialnoho pedahoha yak osnova profesionalizmu [Competence spectrum of the future social pedagogue as the basis of professionalism]. Problemy osvity - Problems of Education, 84, 60-64. [in Ukrainian]

Bohdanova, I. M. (2016). Protses pidhotovky maibutnikh fakhivtsiv sotsionomichnoi sfery [The process of training future specialists of the socionomic sphere]. Naukovyi visnyk Pivdennoukrainskoho natsionalnoho pedahohichnoho universytetu im. K. D. Ushynskoho - Scientific Journal of K.D. Ushinsky Southern Ukrainian National Pedagogical University, 1(108), 13-18. [in Ukrainian]

Honcharenko, S. U. (2010). Pedahohichni doslidzhennia. Metodolohichni porady molodym naukovtsiam [Pedagogical research. Methodological advice for young scientists]. Vinnytsia: Planer. [in Ukrainian]

Hrynova, V. M. (2014). Pro spivvidnoshennia poniat "profesionalizm", "profesiina kultura", "profesiina kompetentnist", "profesiina pidhotovka" [On the correlation of the concepts of "professionalism", "professional culture", "professional competence", "professional training"]. Pedahohika ta psykholohiia Pedagogy and Psychology, 45, 1-11. [in Ukrainian]

Hryshchenko, S. V. (2011). Samovdoskonalennia maibutnikh fakhivtsiv sotsialnoi sfery [Selfimprovement of future specialists in the social sphere]. Chernihiv: ChNPU. [in Ukrainian]

Hurenko, O. (2013). Profesiina pidhotovka sotsialnoho pedahoha: teoretyko-praktychnyi kontekst [Professional training of social teacher: theoretical and practical context]. Donetsk: LANDON-XXI. [in Ukrainian]

Iadov, V. (2007). Strategiia sotsiologicheskogo issledovaniia. Opisanie, obieiasnenie, ponimanie sotsialnoi realnosti [The strategy of sociological research. Description, explanation, understanding of social reality]. Moscow: Omega-L. [in Russian]

Kaydalova, L. G. (2008). Formuvannia profesiinoi kompetentnosti maibutnikh fakhivtsiv [Formation of professional competence of future specialists]. Pedahohika, psykholohiia ta medyko-biolohichni problemy fizychnoho vykhovannia i sportu - Pedagogy, Psychology and Medical-Biological Problems of Physical Education and Sports, 1, 60-63. [in Ukrainian]

Kapska, A. Y. (2010). Deiaki aspekty profesiinoi pidhotovky sotsialnykh pedahohiv i sotsialnykh pratsivnykiv [Some aspects of the professional training of social educators and social workers]. Visnyk Hlukhivskoho natsionalnoho pedahohichnoho universytetu im. O. Dovzhenka - Bulletin of O. Dovzhenko Glukhiv National Pedagogical University, 15,12-16.[in Ukrainian] 
Karpenko, O. H. (2007). Profesiina pidhotovka sotsialnykh pratsivnykiv $v$ umovakh universytetskoi osvity: naukovo-metodychnyi ta orhanizatsiino-tekhnolohichnyi aspekty [Professional training of social workers in the conditions of university education: scientificmethodical and organizational-technological aspects]. Drohobych: Kolo. [in Ukrainian]

Kharchenko, S. Ya. (2006). Sotsializatsiia ditei ta molodi $u$ protsesi sotsialno-pedahohichnoi diialnosti: teoriia $i$ praktyka [Socialization of children and youth in the process of sociopedagogical activity: theory and practice]. Lugansk: Alma mater. [in Ukrainian]

Kostina, V. (2017). Model of professional competence of future social pedagogues and social workers to prevent maladjustment of pupils. In A. Bereza (Ed.), Development and modernization of pedagogical and psychological sciences: experience of Poland and prospects of Ukraine (pp. 1-19). Lublin: "Baltija Publishing".

Kostina, V. (2018). System of training of future social pedagogues and social workers to prevent maladjustment of students. In M. Kiedrowska (Ed.), European vector of contemporary psychology, pedagogy and social sciences: the experience of Ukraine and the Republic of Poland (pp. 160-181). Sandomierz: "Baltija Publishing".

Kraevskii, V. V. (2001). Metodologiia pedagogiki [Methodology of Pedagogy]. Cheboksary. [in Russian]

Kyverialg, A. A. (1980). Metody issledovaniia v professionalnoi pedagogike [Research methods in professional pedagogy]. Tallin: Valgus. [in Russian]

Melnyk, Yu. (2017). Study of trends of students' demand for the formation of competences by higher educational institutions. Science and Education, 5, 128-134. doi:10.24195/24144665-2017-5-22

Melnyk, Yu., \& Pypenko, I. (2017). Innovative potential of modern specialist: the essence and content. In Yu. B. Melnyk (Ed.), Psychological and pedagogical problems of modern specialist formation (pp. 9-16). Warsaw: ANAGRAM. doi:10.26697/9789669726094.2017.9

Mishchyk, L. I. (1997). Teoretyko-metodychni osnovy profesiinoi pidhotovky sotsialnoho pedahoha $u$ zakladakh vyshchoi osvity [Theoretical and methodological foundations of vocational training of social teacher in higher education institutions]. (Doctoral dissertation, Zaporizhzhia State University, Zaporizhzhia, Ukraine). Retrieved from http://www.lib.uaru.net/diss/cont/34563.html [in Ukrainian]

Olefir, V. O. (2016). Psykholohiia samorehuliatsii subiekta diialnosti [Psychology of selfregulation of the subject of activity]. (Doctoral dissertation, Kharkiv Engineering and Pedagogical Academy, Kharkiv, Ukraine). Retrieved from http://www.pdpu.edu.ua/doc/vr/olefir/dis.pdf [in Ukrainian]

Polishchuk, V. (2011). Stanovlennia profesionalizmu sotsialnoho pedahoha na osnovi komponentiv indyvidualnoho styliu yoho diialnosti [Becoming a professional social teacher based on the components of the individual style of his activity]. Molod i rynok - Youth and the Market, 4, 38-43. [in Ukrainian]

Teslenko, V. V. (2007). Teoriia i praktyka sotsialnopedahohichnoi pidtrymky ditei z obmezhenymy mozhlyvostiamy $v$ promyslovomu rehioni [Theory and practice of social and pedagogical support of children with disabilities in the industrial region] $\left(2^{\text {nd }}\right.$ ed.). Lugansk: Alma mater. [in Ukrainian]

Vainola, R. Kh. (2009). Pedahohichni zasady osobystisnoho rozvytku maibutnoho sotsialnoho pedahoha $v$ protsesi profesiinoi pidhotovky [Pedagogical bases of personal development of the future social pedagogue in the process of professional training]. (Doctoral dissertation, M. P. Drahomanov National Pedagogical University, Kyiv, Ukraine). Retrieved from http://www.enpuir.npu.edu.ua/bitstream/123456 789/125/3/Vainola.pdf [in Ukrainian]

Zvierieva, I. D. (Ed.). (2013). Entsyklopediia dlia fakhivtsiv sotsialnoi sfery [Encyclopedia for professionals in the social sphere]. Kyiv, Symferopol: Universum. [in Ukrainian]

\section{Cite this article as:}

Kostina, V. V. (2018). Verification of the system of preparation of future specialists of the social sphere for the prevention of maladjustment of pupils in various social institutions. International Journal of Science Annals, 1(1-2), 12-20. doi:10.26697/ijsa.2018.1-2.02

The electronic version of this article is the complete one and can be found online at: http://ijsa.culturehealth.org/en/archive

This is an Open Access article distributed under the terms of the Creative Commons Attribution License, which permits unrestricted use, distribution, and reproduction in any medium, provided the original work is properly cited (http://creativecommons.org/licenses/by/4.0/deed.en). 